\title{
Diffusion of drugs in hydrogels based on (meth)acrylates, poly(alkylene glycol) (meth)acrylates and itaconic acid
}

\author{
Marija M. Babić ${ }^{1}$, Jovana S. Jovašević ${ }^{2}$, Jovanka M. Filipović ${ }^{2}$, Simonida Lj. Tomić ${ }^{2}$ \\ ${ }^{1}$ Institute "Kirilo Savić", Belgrade, Serbia \\ ${ }^{2}$ University of Belgrade, Faculty of Technology and Metallurgy, Belgrade, Serbia
}

\begin{abstract}
The aim of this paper is to propose equations for the diffusion of drugs for investigated drug/hydrogel systems using the parameters affecting the transport of drug through poly(2-hydroxyethylmethacrylate/itaconic acid) (P(HEMA/IA)), poly(2-hydroxyethylacrylate/itaconic acid) (P(HEA/IA)), and poly(2-hydroxyethylmethacrylate/poly(alkyleneglycol) (meth)acrylates) ( $\mathrm{P}(\mathrm{HEMA} / \mathrm{BIS})$ ) copolymeric hydrogels. Different monomer types, as well as the variable content of some components in hydrogel composition (the amount of ionizable comonomer (IA) and different type of nonionic poly(alkyleneglycol) (meth)acrylates), ultimately defined the pore size available for drug diffusion. The hydrogels synthesized ranged from nonporous to microporous, based on the classification in accordance to the pore size, and could be classified as hydrogels that contain ionic groups and hydrogels without ionic groups. The drugs selected for this study are bronchodilators-theophylline (TPH), fenethylline hydrochloride (FE), and antibiotic cephalexin (CEX). Results of in vitro drug release tests defined the release systems based on the drug type, as well as the type of hydrogel used. The diffusion coefficient of drugs and the restriction coefficient, $\lambda$, defined as the ratio of solute to "pore" radius $\left(r_{s} / r_{\zeta}\right)$ that describes the ease of drug release from the gels, were used as factors that govern the release process.
\end{abstract}

Keywords: hydrogels; 2-hydroxyethyl methacrylate; 2-hydroxyethyl acrylate; poly(alkylene glycol) (meth)acrylates; itaconic acid; controlled drug release; controlled drug release parameters; diffusion equations.

SCIENTIFIC PAPER
UDC 544.773.432:66:661.12

Hem. Ind. 66 (6) 823-829 (2012)

doi: 10.2298/HEMIND120406073B

Available online at the Journal website: http://www.ache.org.rs/HI/

Hydrogels are hydrophilic, crosslinked polymers made of homo- or copolymers that can absorb significant amounts of water or biological fluids but do not dissolve owing to the presence of chemical or physical crosslinks [1-3]. Their hydrophilic surface is characterized by a low interfacial free energy in contact with body fluids, which results in a low tendency for proteins and cells to adhere to these surfaces. Hydrogels resemble natural living tissue more than any other class of synthetic biomaterials. This is due to their high water contents and soft consistency, which is similar to natural tissue. Furthermore, the high water content of the materials contributes to their biocompatibility. Therefore hydrogels have found widespread biomedical and pharmaceutical applications as medical devices (contact lenses, artificial hearts and skin), and as controlled drug delivery systems [4-8].

Special types of hydrogels known as stimuli-responsive have been investigated for the development of "smart" materials in various fields. The term "stimuliresponsive" implies that significant changes of key pro-

Correspondence: S. Lj. Tomić, Faculty of Technology and Metallurgy, University of Belgrade, Karnegijeva 4, 11000 Belgrade, Serbia.

E-mail: simonida@tmf.bg.ac.rs

Paper received: 6 April, 2012

Paper accepted: 28 June, 2012 perties can be induced by an external stimulus, such as $\mathrm{pH}$ value, temperature, ionic strength, pressure, light, or electrical and magnetic fields [5].

Due to their excellent characteristics poly(2-hydroxyethylmethacrylate) (PHEMA), poly(2-hydroxyethylacrylate) (PHEA), itaconic acid (IA) and poly(alkyleneglycol) (meth)acrylates (BIS) are favorable as components of "smart" materials. PHEMA has excellent biocompatibility and physicochemical properties similar to those of living tissues $[9,10]$. PHEA has similar biocompatibility, cytotoxicity, low thrombogenicity, and cell compatibility to the widely studied PHEMA, but it is a less frequently studied polymer. Compared to PHEMA, PHEA seems to be a better option for the case of simulating the mechanical properties of soft tissues without losing water sorption capacity [11]. Itaconic acid (IA) easily copolymerizes and provides polymer chains with carboxylic side groups, which are highly hydrophilic and able to form hydrogen bonds with corresponding groups or ionize at adequate $\mathrm{pH}$ values. The addition of very small amounts of IA to HEMA and HEA hydrogels renders good $\mathrm{pH}$ sensitivity and increases the degree of hydrogel swelling [12-16]. Furthermore, IA is expected to show high biocompatibility because of its natural source [17]. Due to good biocompatibility and safe toxicity profile, poly(ethylene glycol)s (PEGs) are applied 
in various biomedical areas such as drug delivery, wound healing, and tissue repair systems [18-21].

Poly(2-hydroxyethylmethacrylate/itaconic acid) (P(HEMA/IA)), poly(2-hydroxyethylacrylate/itaconic acid) $(P(H E A / I A))$, and poly(2-hydroxyethylmethacrylate)/poly(alkyleneglycol) (meth)acrylates (P(HEMA/BIS)) copolymeric hydrogels, which were characterized in our earlier papers [12-16], showed significant potential for application in drug delivery systems. The drug release studies were carried out in vitro, using bronchodilators-theophylline (TPH) and fenethylline hydrochloride (FE), and antibiotic cephalexin (CEX). In order to give deeper insight into controlled release of used drugs from these hydrogels, as a function of gel structure and morphology, its water sorption capabilities and the drug type, model equations describing solute diffusion through these hydrogels have been proposed for each drug/hydrogel system.

\section{EXPERIMENTAL}

\section{Materials}

2-Hydroxyethyl methacrylate (HEMA) (Aldrich), 2-hydroxyethyl acrylate (HEA) (Aldrich), itaconic acid (IA) (Fluka), and different poly(alkylene glycol) (meth)acrylates (BIS) (BIS1-poly(ethylene glycol) 5 monoacrylate, BIS2-poly(propylene glycol) 6 monomethacrylate, BIS3-poly(ethylene glycol) 6 (propylene glycol) $)_{3}$ monomethacrylate, and BIS4-poly(ethylene glycol) ${ }_{3}$ (propylene gly$\mathrm{col}_{6}$ monomethacrylate) (Laporte Chemicals) were used as components for hydrogel preparation. All polymerizations were performed in a mixture of water/ /ethanol as solvent. Ethyleneglycol dimethacrylate (EGDMA, Aldrich) was used as crosslinking agent and potassium persulfate (KPS, Fluka) and $N, N, N^{\prime}, N^{\prime}$-tetramethylethylene diamine (TEMED, Aldrich) as initiator and activator, respectively. Theophylline (TPH) (Sigma), fenethylline hydrochloride (FE) (Sigma) and cephalexin (CEX) (Sigma) were used as drugs (Figure 1). Buffer solution was prepared using potassium mono and dihydrogenphosphate (Fluka) and sodium hydroxide (Fluka). Demineralized water was used for all polymerizations and the preparation of the buffer solutions.

\section{Preparation of hydrogels}

The $P(H E M A / I A)$ and $P(H E M A / B I S)$ hydrogels were prepared by gamma radiation induced crosslinking/ /polimerization. The reaction solutions were irradiated in a ${ }^{60} \mathrm{Co}$ radiation source, under ambient conditions, at a dose rate of $0.5 \mathrm{kGy} / \mathrm{h}$, to an absorbed dose of 25 kGy. The $P(H E A / I A)$ hydrogels were prepared by free radical crosslinking/copolymerization. The initiator, activator and crosslinker were added to the monomer feed mixture dissolved in water/ethanol mixture. The reaction mixture was degassed prior to polymerization and placed between two glass plates sealed with a rubber spacer ( $2 \mathrm{~mm}$ thick). The polymerizations were carried out at $50{ }^{\circ} \mathrm{C}$ for $24 \mathrm{~h}$. After the reaction, the gels were cut into discs and immersed in water for a week, to remove unreacted components. The water was changed daily. The discs were dried to xerogels.

The amount of uncrosslinked IA was determined by titration of extract against $\mathrm{NaOH}(0.05 \mathrm{~mol} / \mathrm{l})$ to phenolphthalein end point. On the other hand, the amount of uncrosslinked HEMA and BIS were determined using a UV spectroscopy. In all cases, the results indicate that the conversion during cross-linking reaction was nearly complete.<smiles>Cn1c(=O)c2[nH]cnc2n(C)c1=O</smiles><smiles>CC(CCc1ccccc1)NCCn1cnc2c1c(=O)n(C)c(=O)n2C</smiles><smiles>CC1=C(C(=O)O)N2C(=O)[C@@H](NC(=O)[C@@H](N)c3ccccc3)[C@H]2SC1</smiles>

\section{TPH}

FE

\section{CEX}

Figure 1. Chemical structures of used drugs - theophylline (TPH), fenethylline hydrochloride (FE), and cephalexin (CEX). 


\section{Drug release study}

The drug powder (about 5\% of the xerogel weight) was dissolved in water. All xerogel discs were immersed in drug solution and swollen to equilibrium. The swollen drug-loaded samples were then dried at ambient temperature for several days to constant mass and used for the release experiments. Release studies have been carried out in vitro by placing the dried and loaded sample in a definite volume of the release medium (a buffer of pH 7.40 (simulated physiological fluid)) at $37{ }^{\circ} \mathrm{C}$. The amount of drug released was measured using a UV spectrophotometer (Shimadzu UV-Vis spectrophotometer UV-1800), by taking the absorbance of the solution at regular time intervals, at a wavelength of 272, 274, and $262 \mathrm{~nm}$ for TPH, FE and CEX, respectively. These measurements were repeated in triplicate. The concentration of the drug in the external solution at any selected time, $c_{t}$, was calculated from the corresponding calibration curve of the absorbance against drug concentration. The data were analysed using the commercial Origin Microcal 8.0 software.

\section{RESULTS AND DISCUSSION}

\section{Diffusion properties of drug/hydrogel systems}

The release of drug molecules from hydrogels depends on the characteristics of the network: the polymer chemical structure and the network morphology. On the other hand, the physicochemical properties of the drugs also influence the release behavior.

Drug transport in hydrogels can be analyzed using the frictional characteristics of the spherical solutes (drugs) as they diffuse through cylindrical pores. Derivation of drug transport through pores is based on the equation of drug flux with additional hindrance terms for convection and restrictions due to the tortuosity of the transport path. The apparent diffusion coefficient for the drug diffusion in a gel, $D_{d(\text { gel), }}$ relative to the diffusion coefficient of the solute in the liquid at infinite dilution, $D_{d \text { (water), }}$ is related to the restriction coefficient, $\lambda$, defined as the ratio of drug radius to hydrogel pore size. The coefficient $\lambda$ combines the influence of polymeric network structure and the size of the drug on release and transport properties. The diffusion coefficients for solute diffusion in a gel, $D_{d(\mathrm{gel})}$, is calculated from Eq. (1), with the mass transfer principles based on Fick's law [22]:

$D_{d(g e l)}=\frac{k^{2} \pi^{2} l}{16}$

where $k$ is kinetic constant obtained from dynamic release studies (dependence $c_{t} / c_{e}$ on $t$ ) and $l$ is the thickness of the gel. The hydrodynamic radius of the drug molecule, $r_{d}$, was calculated assuming a spherical shape [23], from relation (2):

$\left(r_{d}\right)^{2}=\left(\frac{3 V}{4 \pi N_{\mathrm{A}}}\right)^{2 / 3}$

where $N_{\mathrm{A}}$ is Avogadro's number, $V$ is the molar volume of the drug, calculated from the partial specific volume of the atomic contribution of Le Bas [24]. The calculated values of the hydrodynamic radii are presented in Table 1.

Table 1. Values of molecular weights, $M_{d}$, hydrodynamic radii, $r_{d}$, and bulk diffusion coefficients, $D_{d(\text { water })}$, of the drugs

\begin{tabular}{lccc}
\hline Drug & $M_{d} / \mathrm{g} \mathrm{mol}^{-1}$ & $r_{d} / \mathrm{nm}$ & $D_{d(\text { water })} \times 10^{6} / \mathrm{cm}^{2} \mathrm{~s}^{-1}$ \\
\hline TPH & 180.2 & 0.36 & 9.02 \\
FE & 362.5 & 0.51 & 6.44 \\
CEX & 347.4 & 0.51 & 6.44 \\
\hline
\end{tabular}

The drug diffusion coefficient in the liquid at infinite dilution $D_{d(\text { water })}$ was calculated for each drug employed in this investigation (Table 1), using the Stokes-Einstein Equation:

$D_{d(\text { water })}=\frac{k T}{6 \pi \eta r_{d}}$

where $k$ is the Boltzmann constant, $T$ is the absolute temperature, $\eta$ is the solvent viscosity and $r_{d}$ is the hydrodynamic radius of the drug. In general, a solute is considered to follow Stokes law if the solvent can be treated as a continuum (i.e., $r_{\text {drug }} \gg>r_{\text {solvent }}$ ).

The mean pore size, $\xi$, of hydrogels was calculated from [25], using relation (4):

$\xi=\varphi_{2}^{-1 / 3} /\left(\frac{2 C_{n} \bar{M}_{\mathrm{c}}}{M_{\mathrm{r}}}\right)^{1 / 2}$

where $\phi_{2}$ is volume fraction of the swollen polymer, $I$ is the carbon-carbon single bond length $(0.154 \mathrm{~nm}), C_{n}$ is the rigidity factor of the polymer [15], $M_{c}$ is the average molar mass between the crosslinks [15] and $M_{\mathrm{r}}$ is the molar mass of repeat unit. The calculated mean pore size $\xi$ of the hydrogels (from aforementioned relation) ranged from 0.85 to $3.89 \mathrm{~nm}$ for $\mathrm{P}(\mathrm{HEMA} / \mathrm{IA}), 0.18-$ $-2.21 \mathrm{~nm}$ for $\mathrm{P}(\mathrm{HEMA} / \mathrm{BIS}$ ) (nonporous), and 1.45-24.9 $\mathrm{nm}$ for $\mathrm{P}(\mathrm{HEA} / \mathrm{IA})$ hydrogels (microporous).

The diffusion coefficients of the drugs and drug release exponents, $n$, for $\mathrm{P}(\mathrm{HEMA} / \mathrm{IA}), \mathrm{P}(\mathrm{HEMA} / \mathrm{BIS})$, and $P(H E A / I A)$ hydrogels, obtained from the results of drug release studies, are presented in Table 2 . The values of drug release exponents $n$ are near 0.5 in all cases (Table 2), suggesting that the release process can be described by a Fickian transport mechanism. 
Table 2. Diffusion parameters of the investigated drug/hydrogel systems

\begin{tabular}{lcccc}
\hline Drug & Hydrogel & $k$ & $n$ & $D_{d(\text { gel })} \times 10^{7} / \mathrm{cm}^{2} \mathrm{~s}^{-1}$ \\
\hline TPH & PHEMA & 0.30 & 0.44 & 0.79 \\
& P(HEMA/2IA $)$ & 0.31 & 0.45 & 0.88 \\
& P(HEMA/3.5IA) & 0.34 & 0.46 & 1.23 \\
& P(HEMA/5IA $)$ & 0.50 & 0.52 & 1.55 \\
FE & PHEMA & 0.23 & 0.46 & 0.43 \\
& P(HEMA/2IA) & 0.24 & 0.49 & 0.55 \\
& P(HEMA/3.5IA) & 0.25 & 0.50 & 0.66 \\
& P(HEMA/5IA) & 0.33 & 0.50 & 0.94 \\
CEX & P(HEMA/BIS1) & 0.410 & 0.38 & 24.43 \\
& P(HEMA/BIS2) & 0.240 & 0.35 & 21.53 \\
& P(HEMA/BIS3) & 0.195 & 0.30 & 13.94 \\
& P(HEMA/BIS4) & 0.151 & 0.29 & 4.05 \\
& PHEA & 0.46 & 0.52 & 2.26 \\
& P(HEA/2IA) & 0.57 & 0.52 & 3.51 \\
& P(HEA/3.5IA $)$ & 0.63 & 0.47 & 4.62 \\
& P(HEA/5IA) & 0.68 & 0.51 & 4.76 \\
\hline
\end{tabular}

\section{Drug transport in hydrogels}

Among controlled release drug delivery systems, hydrogels are interesting due to their unique tunable time-dependent swelling behavior. The purpose of controlled release systems is to deliver the drug at specified rate to a desired target, keeping the drug concentration in the body at the therapeutically effective level, with the convenient drug release profile [24].

The structure of drugs: theophylline (TPH), fenethylline hydrochloride (FE), and cephalexin (CEX), used for the investigation of the drug release behavior of hydrogels prepared in this study, are presented in Figure 1. The bronchodilatators theophylline (TPH) and fenethylline hydrochloride (FE), loaded in P(HEMA/IA) hydrogels, contain $-\mathrm{HN}$ - functional groups and the antibiotic cephalexine (CEX) $\left(\mathrm{p} K_{\mathrm{a}}=11.9\right)$, loaded in $\mathrm{P}(\mathrm{HEMA} / \mathrm{BIS})$ and $\mathrm{P}(\mathrm{HEA} / \mathrm{IA})$ hydrogels, contains $-\mathrm{NH}_{2}$ and $-\mathrm{COOH}$ functional groups which can interact effectively with hydrogel functional groups $\left(\mathrm{COO}^{-}, \mathrm{OH}\right)$ through ionic or hydrogen bonds. Hydrogen bonds can be formed also between -OH groups from BIS components of P(HEMA/ /BIS) hydrogels and the functional groups of CEX. Therefore, drug release process in a buffer solution of $\mathrm{pH} 7.4$, at $37^{\circ} \mathrm{C}$ is influenced by the composition of hydrogel.

The drug restriction coefficient $\lambda$ describes the ease of drug release from the gels. As it can be seen from Figures 2 and 3 , the solute transport, presented by normalized diffusion coefficient as a function of $\lambda$, is best correlated by exponential functions for the release of TPH, FE and CEX from P(HEMA/IA), P(HEA/IA) (Figure 2) and $\mathrm{P}(\mathrm{HEMA} / \mathrm{BIS}$ ) hydrogels (Figure 3 ).

The equations which describe the diffusion of TPH and $\mathrm{FE}$ through $\mathrm{P}(\mathrm{HEMA} / \mathrm{IA})$ hydrogels, and CEX diffusion through $\mathrm{P}(\mathrm{HEMA} / \mathrm{BIS})$ and $\mathrm{P}(\mathrm{HEA} / \mathrm{IA})$ hydrogels are presented in Table 3.

The gels investigated can be divided in two groups. In the first group are $\mathrm{pH}$-sensitive networks, $\mathrm{P}(\mathrm{HEMA} /$ /IA) and $P(H E A / I A)$, which contain ionic groups from IA, where hydrogen bonding, physical crosslinks, and electrostatic and hydrophobic interactions can take place with the corresponding functional groups of the drug.

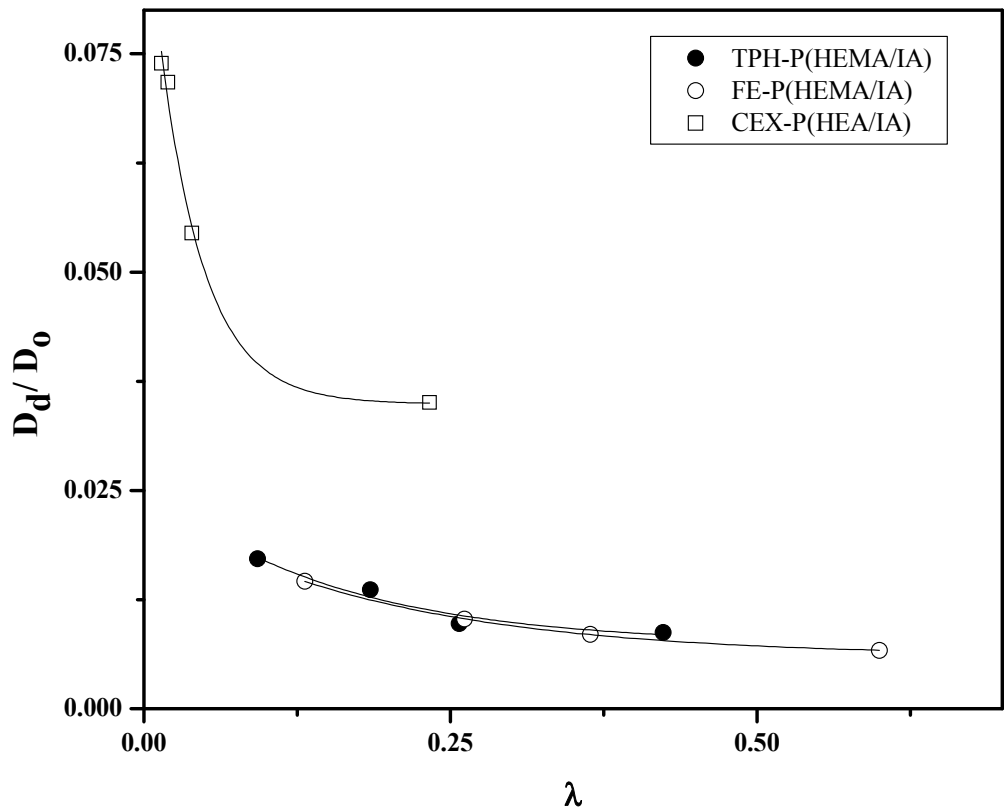

Figure 2. Normalized drug diffusion coefficient for TPH and FE release from $P(H E M A / I A)$ hydrogels, and for CEX release from $P(H E A / I A)$ hydrogels as a function of drug restriction coefficient. 


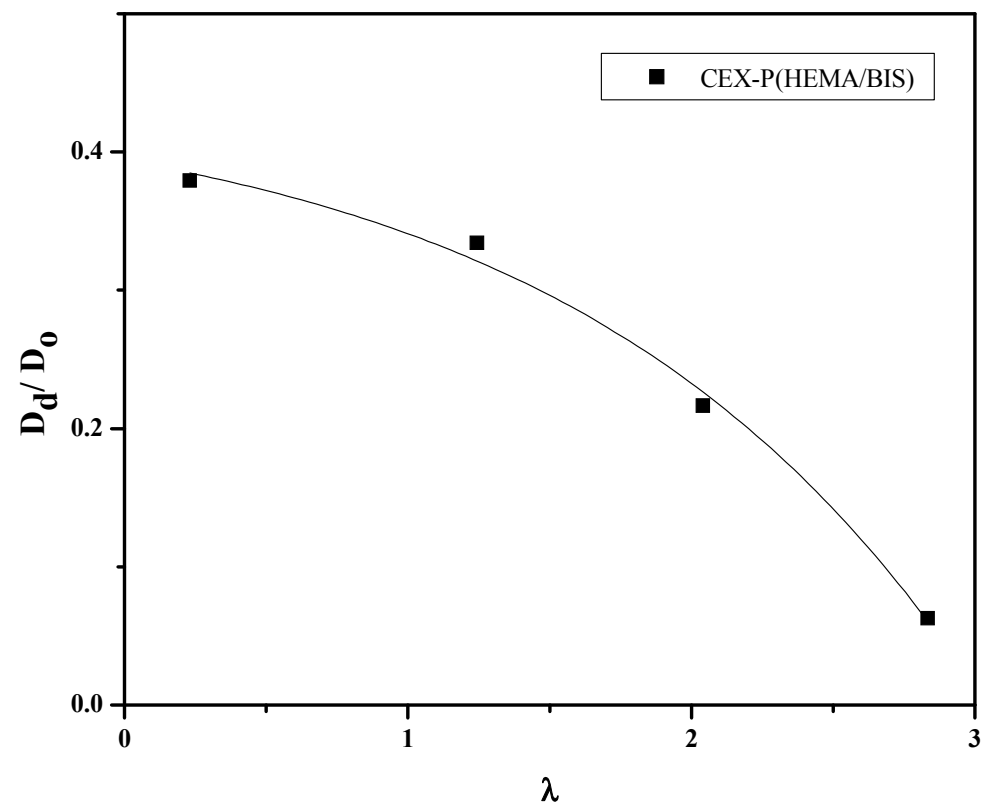

Figure 3. Normalized drug diffusion coefficient for CEX release from P(HEMA/BIS) hydrogels as a function of drug restriction coefficient.

In the second group are the nonionic $\mathrm{P}$ (HEMA/BIS) hydrogels, which have no ionic groups so the electrostatic interactions between the gel and the drug do not take place. For the reason of easier comparison, drugs with similar dimensions were chosen.

When the polymer network is $\mathrm{pH}$-sensitive, the drug is entrained within a network so the drug release is a function of the expansion of the $\mathrm{pH}$-sensitive network, which is regulated by the monomer ratio, the cross-linking density and the $\mathrm{pH}$ value of the swelling media. In our experiments, the drug release studies were performed in a buffer of $\mathrm{pH}$ 7.4, which is higher than both $\mathrm{p} K_{\mathrm{a}}$ values of IA, so practically all IA residues in the polymeric network are ionized. Since the monomer ratio is varied in our copolymer samples it is evident that the drug release is faster for the gels with higher IA content. For the gel containing HEMA monomer and ionic groups from IA, THP/P(HEMA/IA) and
FE/P(HEMA/IA), the lowest values for normalized diffusion coefficients were obtained. It is to be expected for two reasons: pores in these systems fall into the nonporous region and interactions between the functional groups of the drugs and of the network chains are taking place. The system CEX/P(HEA/IA) has higher pores in the network (mesoporous region) due to more hydrophilic HEA residues, and the values for normalized diffusion coefficients are higher. In all cases presented in Figure 2, the normalized diffusion coefficients decline exponentially with $\lambda$, but this trend is more pronounced in the case of $\mathrm{CEX} / \mathrm{P}(\mathrm{HEA} / \mathrm{IA})$ system, with higher pores.

In the case of $\mathrm{P}(\mathrm{HEMA} / \mathrm{BIS})$ hydrogels, which are nonionic and have the smallest pores (nonporous region), much higher values of normalized diffusion coefficients were obtained, but the same trend of exponentially declining values with decreasing pore dimen-

Table 3. Proposed diffusion equations for each drug/hydrogel system

\begin{tabular}{lcc}
\hline Drug & Hydrogel & Equation \\
\hline TPH & P(HEMA/IA $)$ & $\frac{D_{d(\text { gel) }}}{D_{d(\text { water })}}=7.38 \times 10^{-3}+18.5 \times 10^{-3} \exp (-6.66 \lambda)$ \\
FE & P(HEMA/IA $)$ & $\frac{D_{d(\text { gel })}}{D_{d(\text { water })}}=5.97 \times 10^{-3}+17.2 \times 10^{-3} \exp (-5.28 \lambda)$ \\
CEX & P(HEA/IA $)$ & $\frac{D_{d(\text { gel })}}{D_{d(\text { water })}}=3.49 \times 10^{-2}+5.99 \times 10^{-2} \exp (-27.62 \lambda)$ \\
CEX & $\frac{D_{d(\text { gel })}}{D_{d(\text { water })}}=0.445-0.051 \exp (0.712 \lambda)$ \\
\hline
\end{tabular}


sions is present. This behavior confirms that the diffusion of drugs depend more on the interactions (most of all electrostatic) between the drug and network chains and less on the pore size.

\section{CONCLUSION}

Mathematical equations describing the diffusion of model drugs through drug delivery systems based on 2-hydroxyethyl methacrylate (HEMA), and 2-hydroxyethyl acrylate (HEA), different poly(alkylene glycol) (meth)acrylates (BIS) and itaconic acid (IA) were obtained. Hydrogels were prepared by gamma-radiation induced crosslinking/polymerization, and chemically crosslinking/polymerization. Antibiotic cephalexin (CEX), and bronchodilatators theophylline (TPH) and fenethylline hydrochloride (FE) were used as model drugs. The release of drugs from these hydrogels was investigated in vitro, in a buffer of $\mathrm{pH} 7.4$, at $37^{\circ} \mathrm{C}$. The results of in vitro drug release studies showed that our release systems were determined by the type of drug, as well as by the type of hydrogel. The equations which describe the diffusion of TPH and FE through P(HEMA/IA) hydrogels, and CEX diffusion through $P(H E M A / B I S)$ and $\mathrm{P}(\mathrm{HEA} / \mathrm{IA})$ hydrogels are given by the normalized diffusion coefficient, $\left.D_{d(\text { gel })}\right) /\left(D_{d(\text { water) }}\right.$, as a function of the restriction coefficient, $\lambda$. The dependence of normalized diffusion coefficient on $\lambda$, are best correlated by exponential function in all cases. From the relations obtained it can be said that the diffusion of drugs, depend more on the interactions (most of all electrostatic) between the drug and network chains and less on the pore size.

\section{Acknowledgment}

This work has been supported by the Ministry of Education, Science and Technological Development of the Republic of Serbia (Grants No. 172026 and 172062).

\section{REFERENCES}

[1] J. Kopecek, J. Yang, Hydrogels as smart biomaterials, Polym. Int. 56 (2007) 1078-1098.

[2] S. Chaterji, I.K. Kwon, K. Park, Smart polymeric gels: Redefining the limits of biomedical devices, Prog. Polym. Sci. 32 (2007) 1083-1122.

[3] M.W. Urban, Stratification, stimuli-responsiveness, selfhealing, and signaling in polymer networks, Prog. Polym. Sci. 34 (2009) 679-687.

[4] Y. Dai, P. Li, A. Wang, Intelligent drug delivery system of intelligent high polymer materials, Prog. Chem. 19 (2007) 362-369.

[5] Y. Qiu, K. Park, Environment-sensitive hydrogels for drug delivery, Adv. Drug Deliver. Rev. 53 (2001) 321-339.

[6] N.A. Peppas, Y. Huang, M. Torres-Lugo, J.H. Ward, J. Zhang, Physicochemical foundations and structural de- sign of hydrogels in medicine and biology, Annu. Rev. Biomed. Eng. 2 (2000) 9-29.

[7] A. Kumar, A. Srivastava, I.Y. Galaev, B. Mattiasson, Smart polymers: Physical forms and bioengineering applications, Prog. Polym. Sci. 32 (2007) 1205-1237.

[8] B. Schmaljohann, Thermo- and pH-responsive polymers in drug delivery, Adv. Drug. Delivery Rev. 58 (2006) 1655-1670.

[9] S. Brahim, D. Narinesingh, A.G. Elie, Synthesis and hydration properties of $\mathrm{pH}$-sensitive $\mathrm{p}(\mathrm{HEMA})$-based hydrogels containing 3-(trimethoxysilyl)propyl methacrylate, Biomacromolecules 4 (2003) 497-503.

[10] S. Lahooti, M.V. Sefton, Microencapsulation of normal and transfected L929 fibroblasts in a HEMA-MMA copolymer, Tissue Eng. 6 (2000) 139-149.

[11] G. Gallego Ferrer, M. Salmerón Sánchez, J.L. Gómez Ribelles, F.J. Romero Colomer, M. Monleón Pradas, Nanodomains in a hydroplylic-hydrophobic IPN based on poly(2-hydroxyethyl acrylate) andpoly(ethyl acrylate), Eur. Polym. J. 43 (2007) 3136-3145.

[12] S.Lj. Tomić, E.H. Suljovrujić, J.M. Filipović, Biocompatible and bioadhesive hydrogels based on 2-hydroxyethyl methacrylate, monofunctional poly(alkylene glycol)s and itaconic acid, Polym. Bull. 57 (2006) 691-702.

[13] S.Lj. Tomić, M.M. Mićić, S.N. Dobić, J.M. Filipović, E.H. Suljovrujić, Smart poly(2-hydroxyethylmethacrylate/itaconicacid) hydrogels for biomedical application, Radiat. Phys. Chem. 79 (2010) 643-649.

[14] S.Lj. Tomić, M.M. Mićić, J.M. Filipović, E.H. Suljovrujić, Swelling and drug release behavior of poly(2-hydroxyethyl methacrylate/itaconic acid) copolymeric hydrogels obtained by gamma irradiation, Radiat. Phys. Chem. 76 (2007) 801-810.

[15] S.Lj. Tomić, M.M. Mićić, J.M. Filipović, E.H. Suljovrujić, Synthesis, characterization and controlled release of cephalexin drug from smart poly(2-hydroxyethyl methacrylate/poly(alkylene glycol)(meth)acrylates hydrogels, Chem. Eng. J. 160 (2010) 801-809.

[16] S.Lj. Tomić, J.S. Jovašević, J.M. Filipović, S.N. Dobić, In vitro cephalexin release study from new poly(2-hydroxyethyl acrylate/itaconic acid) copolymeric hydrogels, 2th Conference Innovation in Drug Delivery, Aix-en-Provence, France, Programme and Abstracts, 2010, p. 154.

[17] M. Pertruccioli, V. Pulchi, F. Federici, Itaconic acid production by Aspergillus terreus on raw starchy materials, Lett. Appl. Microbial. 28 (1999) 309-312.

[18] N.A. Peppas, K.B. Keys, M. Torres-Lugo, A.M. Lowman, Poly(ethylene glycol)-containing hydrogels in drug delivery, J. Control. Release 62 (1999) 81-87.

[19] J.F. Lutz, Polymerization of oligo(ethylene glycol) (meth)acrylates: Toward new generations of smart biocompatible materials, J. Polym. Sci. Pol. Chem. 46 (2008) 3459-3470.

[20] Y.-Z. You, D. Oupicky, Synthesis of temperature-responsive heterobifunctional block copolymers of PEG and PNIPAM, Biomacromolecules 8 (2007) 98-105.

[21] M.Y. Arica, D. Tuglu, M.M. Basar, D. Kilic, G. Bayramoglu, E. Batislam, Preparation and characterization of infection-resistant antibiotics-releasing hydrogels rods of 
poly[hydroxyethyl methacrylate-co-(poly(ethylene glycol)-methacrylate]: Biomedical application in a novel rabbit penile prosthesis model, J. Biomed. Mater. Res., B 86 (2008) 18-28.

[22] C.S. Brazel, N.A. Peppas, Mechanisms of solute and drug transport in relaxing swellable, hydrophilic glassy polymers, Polymer 40 (1999) 3383-3398.

[23] A. Martin, J. Swarbrick, A. Cammarata, Physical Pharmacy-Physical Chemical Principles in the Pharmaceutical
Sciences, $3^{\text {rd }}$ ed., Lea and Febinger, Philadelphia, PA, 1983.

[24] C.R. Wilke, P. Chang, Correlation of diffusion coefficients in dilute solutions, AIChE. J. 1 (1955) 264-270.

[25] S.K. Bajpai, S. Singh, Analysis of swelling behavior of poly(methacrylamide-co-methacrylic acid) hydrogels and effect of synthesis conditions on water uptake, React. Funct. Polym. 66 (2006) 431-440.

\section{IZVOD}

\section{DIFUZIJA LEKOVA U HIDROGELOVIMA NA BAZI (MET)AKRILATA, POLI(ALKILENGLIKOL)-(MET)AKRILATA I ITAKONSKE} KISELINE

Marija M. Babić ${ }^{1}$, Jovana S. Jovašević ${ }^{2}$, Jovanka M. Filipović ${ }^{2}$, Simonida Lj. Tomić $^{2}$

${ }^{1}$ Institut "Kirilo Savić", Beograd, Srbija

${ }^{2}$ Univerzitet u Beogradu, Tehnološko-metalurški fakultet, Beograd, Srbija

(Naučni rad)

Cilj ove studije je da se predlože difuzione jednačine za ispitivane sisteme lek/hidrogel. Korišćeni su hidrogelovi poli(2-hidroksietilmetakrilat/itakonska kiselina) $(\mathrm{P}(\mathrm{HEMA} / \mathrm{IK}))$, poli(2-hidroksietilakrilat/itakonska kiselina) $(\mathrm{P}(\mathrm{HEA} / \mathrm{IK}))$ i poli(2-hidroksietilmetakrilat/poli(alkilenglikol)-(met)akrilati) (P(HEMA/BIS)). Komponenta koja se menja u sastavu hidrogela HEMA, HEA, kao i udeo komponente sa promenljivim sadržajem (udeo jonizujućeg komonomera (IK) i tip BIS komponente) definiše veličinu pora koja je dostupna za difuziju leka. U ovoj studiji su korišćeni lekovi bronhodilatori teofilin (TPH) i fenetilin-hidrohlorid (FE), i antibiotik cefaleksin (CEX). Ovi gelovi su klasifikovani u režimu poroznosti kao neporozni i mikroporozni, sa veličinom pora u opsegu $0,18-24,9 \mathrm{~nm}$. Kontrolisano otpuštanje lekova je izvedeno u in vitro uslovima u puferu $\mathrm{pH} 7,40$ i na $37^{\circ} \mathrm{C}$, da bi se odredili difuzioni koeficijenti leka u hidrogelovima. Na osnovu toga su predložene jednačine difuzije leka kroz hidrogel za svaki sistem lek/hidrogel. Rezultati dobijeni fitovanjem eksperimentalnih podataka su pokazali da difuzija leka zavisi od hemijske strukture i morfologije hidrogela i parametra $\lambda$, koji predstavlja odnos prečnika leka i veličine pora. Eksponencijalna zavisnost koeficijenta restrikcije od normalizovanog koeficijenta difuzije je dobijena za sisteme TPH/P(HEMA/IA), FE/P(HEMA/ /IA), CEX/P(HEMA/BIS) i CEX/P(HEA/IA) .Utvrđeno je da veliki uticaj na difuziju leka imaju interakcije koje se odigravaju između funkcionalnih grupa leka i polimerne mreže.
Ključne reči: hidrogelovi $\bullet$ 2-hidroksietilmetakrilat - 2-Hidroksietilakrilat • Poli(alkilenglikol)-(met)akrilati - Itakonska kiselina • Kontrolisano otpuštanje leka • Parametri kontrolisanog otpuštanja leka - Jednačine difuzije 